УКРАЇНСЬКИЙ АНТАРКТИЧНИЙ
ЖУРНАЛ

УАЖ, № 2, 105-110, (2004)

\title{
UDC 551.510.534
}

\section{TRAVELING PLANETARY WAVES IN OZONE LAYER OVER ANTARCTIC PENINSULA}

\author{
A.V. Grytsai ${ }^{1}$, Z.I. Grytsai ${ }^{1}$, A.M. Evtushevsky ${ }^{1}$, G.P. Milinevsky ${ }^{1,2}$, N.A. Leonov ${ }^{1,2}$ \\ ${ }^{1}$ National Tarasa Shevchenka University, Kyiv, Prosp. Akad. Glushkova, 2/1, 03127 \\ assen@univ.kiev.ua \\ ${ }^{2}$ Ukrainian Antarctic Center, Kyiv, Blvd. Tarasa Shevchenka, 16, 01601 \\ science@uac.gov.ua
}

\begin{abstract}
Preliminary results of the analysis of the traveling planetary wave evolution in the ozone layer over the region of Antarctic Peninsula are presented. Total ozone data obtained at the Vernadsky station and TOMS satellite measurements are used. The main characteristics of the traveling waves, namely the spectral distribution, period, amplitude and velocity were considered. At the station latitude of $65.25^{\circ} \mathrm{S}$ the amplitude of the traveling wave number 2 becomes equal or exceeds the stationary wave number 1 amplitude in individual cases only. In average for the period 1979-2003 the relationship of amplitudes of the wave numbers $1,2,3,4$ and 5 is $1,0.56,0.29,0.19$, and 0.15 . The wave periods $6-8$ and $10-12$ days are dominant. Velocities of $8-10 \mathrm{~m} / \mathrm{s}$ are obtained.
\end{abstract}

Біжучі планетарні хвилі в озоновому шарі над Антарктичним півостровом. А.В. Грицай, 3.І. Грицай, О.М. Євтушевський, Г.П. Міліневський, М.А. Леонов

Реферат. Наводяться попередні результати аналізу еволюції біжучих планетарних хвиль над регіоном Антарктичного півострова. Використано дані вимірювань загального вмісту озону в атмосфері на станції Академік Вернадський та супутникових вимірювань TOMS. Розглянуто основні характеристики біжучих хвиль, зокрема, спектральний розподіл, періоди, амплітуда і швидкість. На широті станції $65.25^{\circ} \mathrm{S}$ амплітуда біжучих хвиль 3 хвильовим числом 2 буває близькою або перевищує амплітуду стаціонарної хвилі 1 лише в окремих випадках. Амплітуди хвильових чисел 1, 2, 3, 4 та 5 в середньому за період 1979-2003 рр. співідносяться як 1, 0.56, 0.29, 0.19 та 0.15. Переважають періоди хвиль 6-8 та 10-12 днів. Швидкості одержано в межах 8-10 м/с.

Key words: ozone layer, planetary wave, Vernadsky Station, TOMS

\section{Introduction}

Planetary waves (PW) in the atmosphere play important role in global scale processes such as meridional stratospheric circulation or energy transport from the troposphere to the higher atmospheric layers. If a horizontal plane to be considered, PW in atmospheric parameters both as quasi-stationary wave distribution over the Earth surface and in form of the traveling waves can be presented.

Traveling planetary waves (TW) with periods of several days to a few weeks are observed in the atmosphere of the northern and southern hemisphere (Randel, 1993; Nathan et al., 1994; Roldugin et al., 2000; Lawrence and Jarvis, 2001). One can see the wave motion in the ozone layer from the sequence of the daily image of the TOMS global ozone distribution during the southern winter/spring season on the TOMS web site (Earth Probe TOMS, 2004). The edge region of the stratospheric polar vortex is especially reach in TW structures. Migrating waves interact with the stationary ones changing their amplitude. If the wave amplitude increases essentially, PW can break and transfer energy to the surrounding stratosphere. This process influences the stratospheric polar vortex stability and becomes one of key factors in the vortex breakdown during Antarctic spring.

Along with other atmospheric parameters, the daily total ozone can be used as an indicator of the wave activity in the stratosphere. For example, the Dynamic Activity Index (DAI) is derived from the TOMS and GOME satellite ozone observations by the World Data Center for Remote Sensing of the Atmosphere (Dynamic Activity, 2004). The DAI-W1 (DAI-W2) index is defined as the daily hemispheric mean of the zonal amplitude of the planetary wave number 1 (2). 
In this work we consider the TW activity in the region of Antarctic Peninsula using the groundbased ozone data from the Vernadsky station $\left(65^{\circ} 15^{\prime} \mathrm{S}, 64^{\circ} 16^{\prime} \mathrm{W}\right)$ and the TOMS satellite ozone data for the latitudinal circle $65^{\circ} 30^{\prime} \mathrm{S}$. Latitudinal location of the Antarctic Peninsula region corresponds to the vortex-edge region in the stratosphere giving an advantage in studying the wave processes in the ozone layer.

\section{Passage of the traveling waves in the ozone layer over Antarctic Peninsula}

To illustrate the process of the traveling wave development in the ozone layer, ozone data from the Vernadsky and TOMS observations during October-December 1999 are presented in Fig. 1 and 2, respectively. The total ozone wave oscillation of large amplitude is seen in Vernadsky data during November - the first week of December (Fig. 1). Comparison with the TOMS satellite data for the southern latitudes $30-90^{\circ} \mathrm{S}$ (Fig. 2) shows the origin of the quasi-sinusoidal change of the total ozone over the station.

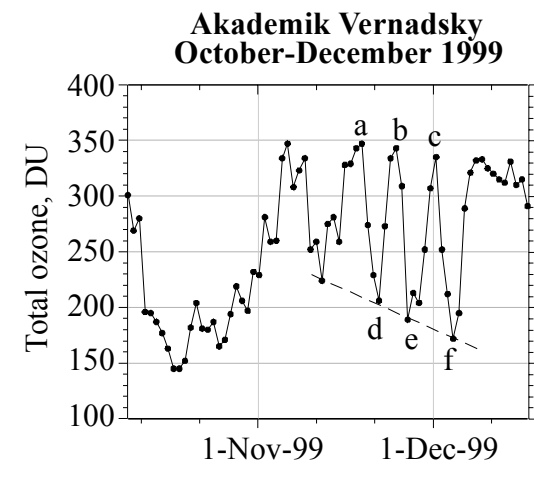

Fig. 1. Periodicity in the daily total ozone change during November - early December 1999 observed with the Dobson spectrophotometer.
Wave disturbance of the ozone hole boundary in the horizontal plane produces the meridional displacement of the stratospheric air masses. Ozone rich air from middle latitude shifted to the pole within the wave trough giving the maximum ozone level when it appears over the station (labeled as a, b, c in Fig. 1 in accordance with the images of Fig. 2, $\mathrm{a}, \mathrm{b}, \mathrm{c})$.

The low ozone air from the inner region of the ozone hole moved towards equator filling the wave ridge, which causes the ozone minimum d, e, f (Fig. 1 and 2, with the same labeling). Eastward zonal motion of the wave ridge/trough (to the arrows in Fig. 2) caused periodic passing over station the stratospheric air with low/high total ozone.

EP-TOMS daily total ozone distribution within the latitudinal band of 30-90 ${ }^{\circ} \mathrm{S}$

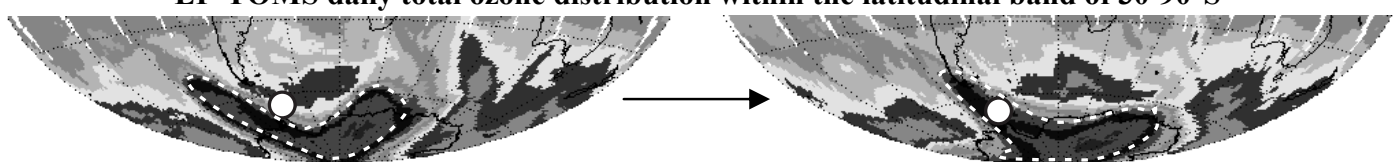

18 November a $\quad$ d November

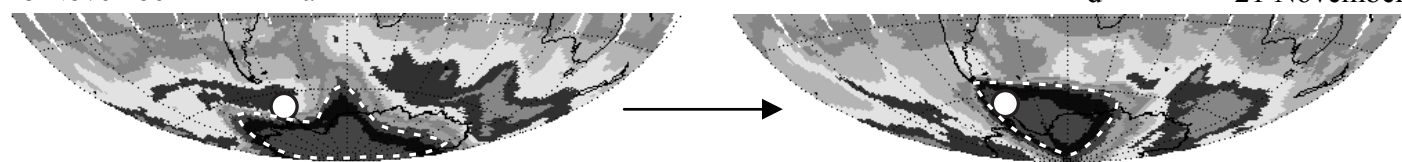

24 November $\quad$ b

e $\quad 26$ November

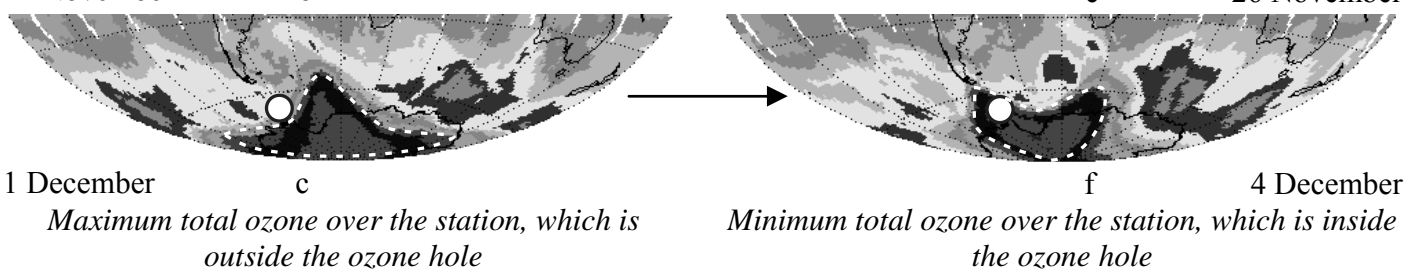

Fig. 2. Alternation of the in- and out-of-hole position of the Vernadsky station (white circle) caused by the traveling wave deformation of the ozone hole. Dates of the images correspond to the days of the maxima (left, a-c) and minima (right, d-f) in the wave ozone oscillation in Fig. 1. The arrows connect the nearest in time out- to in-hole positions of the station. 
Passage of the narrow ridge of the ozone hole over the station caused by the traveling wave repeated three times. The average period of the a-f series of oscillations was 6.8 days. Regularity of this event was unique for Vernadsky and such a quasi-sinusoidal oscillation with the average amplitude of about 150 DU was observed only once.

Due to the displacement of the ozone hole from the pole-centered position towards the South America (Fig. 2, e-f), the polar stratospheric air with more and more low ozone amount moved forward over the station in the wave ridge. This process is seen as the ozone minimum levels decrease measured at Vernadsky (marked by dashed line in Fig. 1). The very late break-up of the stratospheric polar vortex was characteristic for the spring of 1999. A long interval of ozone depletion in the ozone hole and the simultaneous accumulation of the mid-latitude ozone rich air outside the vortex caused the large amplitude of the traveling waves in the ozone layer, which was registered at the station. Finally, mixing of the mid-latitude and polar stratospheric air masses after the ozone hole disintegration resulted in the settling of the total ozone level of about 300 DU since the later December (Fig. 1).

This example demonstrates the local manifestation of the large-scale wave process in the vortex-edge region of the southern stratosphere. The wave ridge and trough in Fig. 2 was formed by the traveling planetary wave of the zonal wave number 2, but decentering of the hole relative to the pole was caused by the stationary planetary wave of the wave number 1 . Note, that the quasistationary PW-1 distribution of the total ozone in the vortex-edge region has minimum in the longitudinal sector of $0-60^{\circ} \mathrm{W}$ (by our analysis presented in the separate publication; see also (Wirth, 1993)). Owing to these circumstances interaction between PW-1 and TW-2, specifically their phases coincidence, results in the elongation of the ozone hole and wave ridges stretching mostly over the region close to Antarctic Peninsula.

\section{Zonal wave number structure of the traveling planetary waves at $65^{\circ} \mathrm{S}$}

Analysis of the event of November 1999 (Fig. 1 and 2) reveals two main components of PW in the ozone layer, namely the wave number 1 and 2 . In this section the preliminary results of the spectral analysis of the TOMS data for zonal wave numbers 1-5 are presented.

In Fig. 3 the three longitudinal profiles of the total ozone along the $65.5^{\circ} \mathrm{S}$ latitude circle from the TOMS daily global distribution are shown. The days were selected, which inherent in the stationary planetary wave structure of the zonal wave number 1 (Fig. 3, a), and superposition of the stationary and traveling wave: PW-1 and TW-2 (Fig. 3, b), and PW-1 and TW-3 (Fig. 3, c). Decrease of the TW amplitude with increase of the wave number is seen.

The change of the daily PW 1-5 amplitude during August-December is shown in Fig. 4. The years of the pre-ozone-hole (1979), intermediate (1988) and recent period (2003) are presented. Each amplitude value was calculated relative to the daily average total ozone along the $65.5^{\circ} \mathrm{S}$ circle.

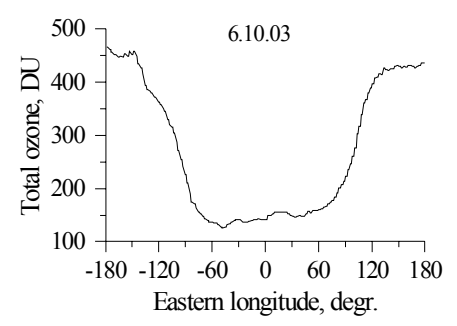

a

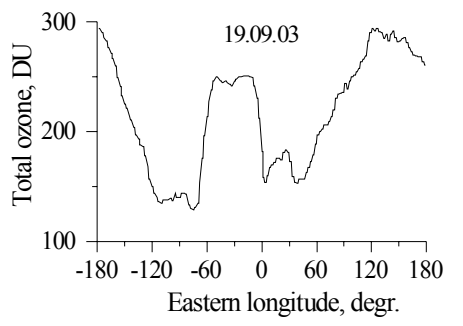

b

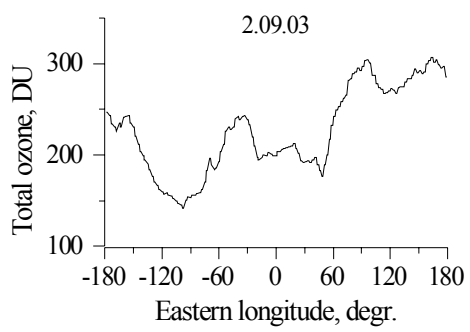

c

Fig. 3. Zonal structure of the stationary planetary wave of the wave number 1 (a) and its superposition with the traveling PW of the wave number 2 (b) and wave number 3 (c) by the TOMS ozone data for $65.5^{\circ} \mathrm{S}$. 
Time intervals when the amplitude of the wave number 2 equals or exceeds the wave number 1 amplitude occur occasionally. Month-to-month change of PW-1 and TW-2 amplitudes exhibits the maximum activity of the waves during September-November.

The interannual variations of the 5-month average amplitude of the wave number 1-5 are shown in Fig. 5. The tendency of the amplitude increase during 1979-2003 is seen for all wave numbers, obviously, as an effect of increasing contrast of the total ozone at the polar and equatorial sides of the polar vortex. Latitudinal difference in the total ozone long-term trend can cause this process, which will be the subject of other study.

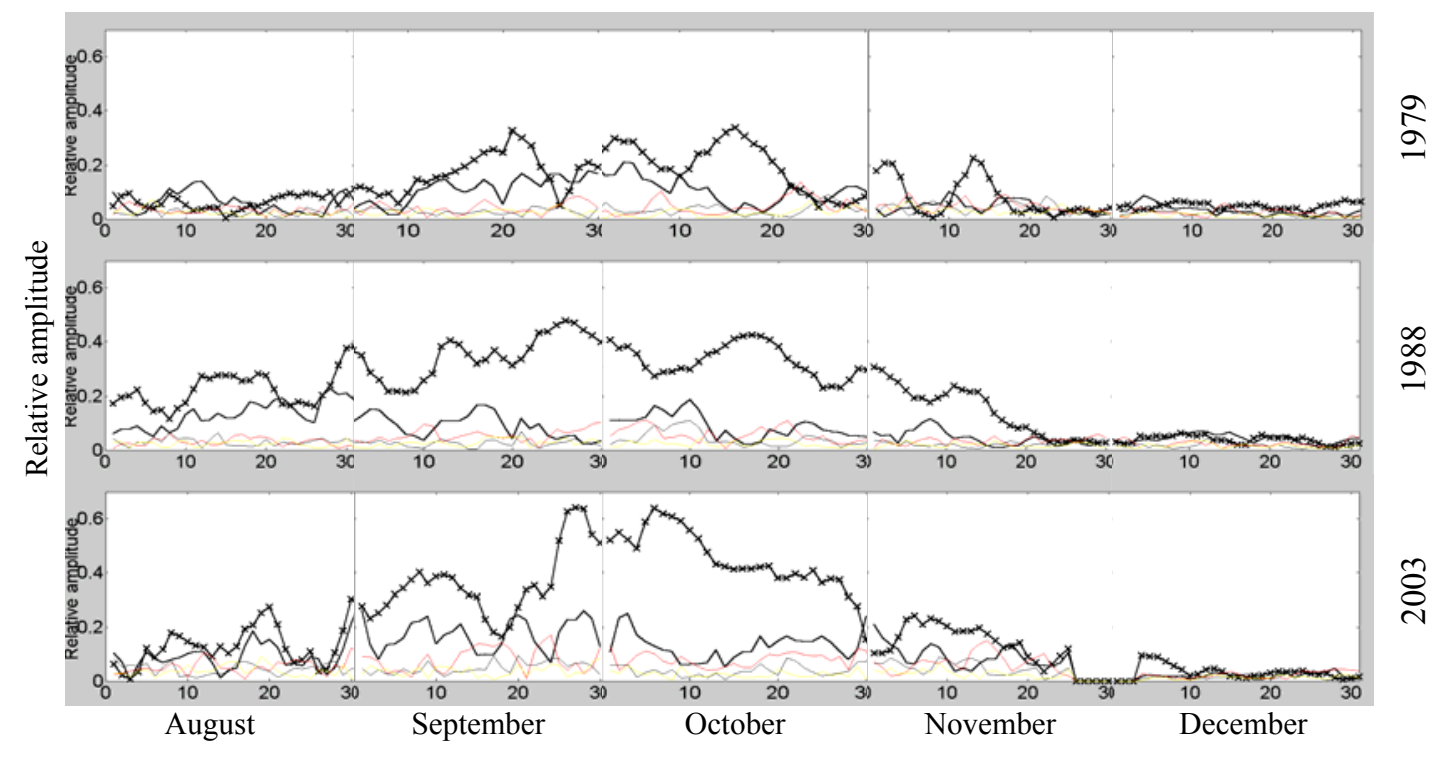

Fig. 4. Daily amplitude change of the planetary wave numbers 1 to 5 during August-December of 1979, 1988, and 2003. The relative amplitudes range on the vertical axes is the same for each of the years. Decreasing line thickness marks increasing wave numbers.

For the 1979-2003 period the relationship of amplitudes of the wave numbers $1,2,3,4$ and 5 is on average $1,0.56,0.29,0.19$, and 0.15 .

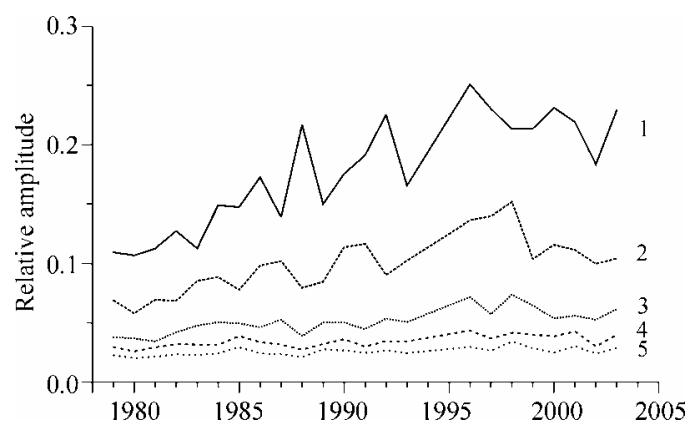

Fig. 5. Interannual change of the planetary wave 1-5 relative amplitude averaged for August-December.

\section{Traveling wave periods}

Traveling wave event of 1999 (Fig. 1) has the period of about 7 days. Spectral analysis for the selected years was made using ozone data from the Vernadsky station (Fig. 6). Variable structure of periodicity is seen. 
In general, the lower values of period are 6-8 days, the middle ones are 10-12 days, and the periods more than 16 days exist also. The periods shorter than 5 days (dashed line in Fig. 6) are practically absent in this data set. It is appropriate to note, that the ground-based measurements during 1986-1990 from the four stations at the northern latitudes $\sim 50^{\circ} \mathrm{N}$ and $70^{\circ} \mathrm{N}$ shows the mean wave periods in the total ozone equal to 12-16 and 12-21 days, respectively (Roldugin et al., 2000). These results do not give even the periods of 5-10 days in the ozone variations. It is possible, that the periodicity of the individual ozone data values (not more frequently, than one value per day) imposes the limitation on the short periods revealing.

Estimation of the traveling wave velocity at $65^{\circ} \mathrm{S}$ gives the values of $8-10 \mathrm{~m} / \mathrm{s}$, which are consistent with the values of up to $13 \mathrm{~m} / \mathrm{s}$ obtained by Roldugin et al. (2000). Note, that the zonal flow velocity in the stratosphere over the southern sub-polar latitudes is tens $\mathrm{m} / \mathrm{s}$ and reaches in excess of $85 \mathrm{~m} / \mathrm{s}$ (Harvey et al., 2002; WMO, 2003).
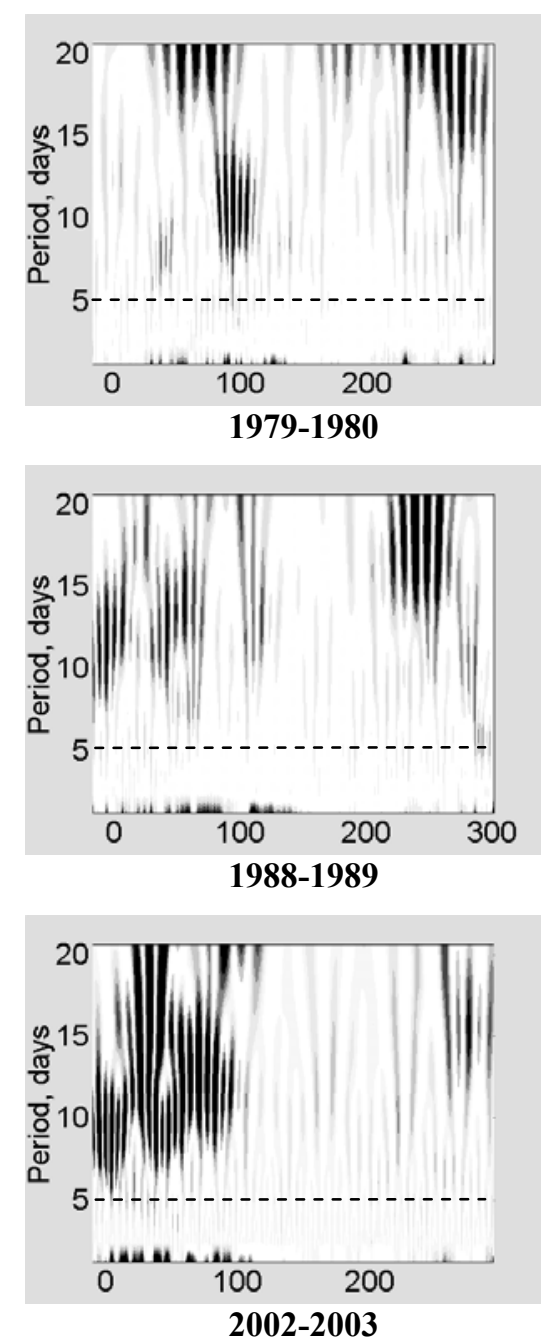

References

Fig. 6. Results of the wavelet transform of the total ozone data sets from Vernadsky. The time interval from July to May (X-axis) was analyzed. Dashed lines mark the 5-day period, which bounds the lower level of periodicity in ozone over Vernadsky.

\section{Conclusion}

Total ozone data from the Vernadsky station and TOMS satellite measurements have been analyzed to reveal the basic characteristics of the traveling planetary waves in the southern sub-polar stratosphere. Preliminary results on the wave number structure, relative amplitude, periods and velocities of traveling waves near $65^{\circ} \mathrm{S}$ are presented.

The region of Antarctic Peninsula is located close to the longitudinal ozone minimum in the stationary wave number 1 distribution. Phase coincidence of stationary and traveling waves gives steady appearance of the low ozone wave ridges stretched towards equator just in this range of the longitudes. So the quantifying of the traveling wave activity and long-term tendencies is important for this region.

Our further analysis will be concerned with month-to-month, interannual and long-term change of the traveling wave periodicity and wave number 1-5 structure during the last decades. It is interesting to consider the TW evolution with regard to preand post-ozone-hole conditions in the stratosphere/troposphere.

This work was partly supported by grants FFD F7/362-2001, MON A/2-2004, and UAC H/8-2004.

Dynamic Activity and Ozone Variability Indices from EP/TOMS. Dynamic Activity Index // http://wdc.dlr.de/data_products/index.html. - 2004. 
Earth Probe TOMS ozone data and images. - http://toms.gsfc.nasa.gov/ftpdata.html. - 2004 .

Harvey V.L., Pierce R.B., Fairlie T.D., Hitchmann M.H. A climatology of stratospheric polar vortices and anticyclones // J. Geophys. Res. - 2002. - Vol. 107, No. D20, 4442, doi: 10.1029/2001JD001471.

Lawrence A.R., Jarvis M.J. Initial comparisons of planetary waves in the stratosphere, mesosphere and ionosphere over Antarctica // Geophys. Res. Let. - 2001. - Vol. 28, No. 2. - P. 203206.

Nathan T.R., Cordero E.C., Li L. Ozone heating and the destabilization of traveling waves during summer // Geophys. Res. Lett. - 1994. - Vol. 21, No. 14. - P. 1531-1534.

Randel W.J. Global normal-mode Rossby waves observed in stratospheric ozone data // J. Atm. Sci. - 1993. - Vol. 50, No. 3. - P. 406-420.

Roldugin V.C., Nikulin G.N., Henriksen K. Wave-like ozone movements // Phys. Chem. Earth. - 2000. - Vol. 25, No 5-6. - P. 511-514.

Weber M., Dhomse S., Wittrock F., et al. Dynamical control of NH and SH winter/spring total ozone from GOME observations in 1995-2002 // Geophys. Res. Lett. - 2003. - Vol. 30, No. 11. doi:10.1029/2002GL016799.

WMO (World Meteorological Organization). Scientific assessment of ozone depletion: 2002. Report 47. - Geneva, 2003. 